12th LUMEN International Scientific Conference Rethinking Social Action. Core Values in Practice | RSACVP 2019 | 15-17 May 2019 | lasi - Romania

\title{
Reducing Regional Disparities: SME's Support Funding Distribution and Effects in the Regions
}

\author{
Liliana-Olivia LUCACIU
}

https://doi.org/10.18662/lumproc.164

How to cite: Lucaciu, L.-O. (2019). Reducing Regional Disparities: SME's Support Funding Distribution and Effects in the Regions. In C. Ignatescu (ed.), 12th LUMEN International Scientific Conference Rethinking Social Action. Core Values in Practice, 15-17 May 2019, Iasi - Romania (pp. 180-196). Iasi, Romania: LUMEN Proceedings. https://doi.org/10.18662/lumproc.164 


\title{
Reducing Regional Disparities: SME's Support Funding Distribution and Effects in the Regions
}

\author{
Liliana-Olivia LUCACIU1
}

\begin{abstract}
The research was conducted in the context of shifting the focus of regional policies from supporting the development of all regions towards the reduction of inter and intraregional disparities. A second contextual element is the stronger recognition of the research potential to build more knowledge for the continuous improvement of the policy making.

The paper aims at providing a model for linking the regional policy objectives, instruments, implementation methods and practice with the effects produced in the regions to inform future policies and address better the new challenges raised by the economic development disparities and social inequalities.

The research was focused on the eight development regions of Romania and the SMEs support funding provided through the Regional Operational Programme 2017-2013, using an extensive database with more than 2100 beneficiaries of funding including data on the development projects implemented as well as on their business performance before and after the project implementation. The research looks at regional differences of the distribution of funding, typology of interventions and their effects as well their links with specific features of the regional disparities before and after the programme implementation. Most relevant factors influencing the impact of the funding on the business performance were analysed, including sizes of the business, location, sector, sizes of the funding.

The research highlights the need to adapt the approaches and instruments to the multidimensional problem of regional disparities using empirical evidence provided through multidisciplinary research.
\end{abstract}

Keywords: impact evaluation; smart growth; competitiveness; regional policies; quantitative methods;

\footnotetext{
$1 \mathrm{PhD}$ candidate, Bucharest University of Economic Studies, Bucharest, Romania, lilianalucaciulg@gmail.com, +40 745609369. 


\section{Introduction}

The paper aims to respond to the needs of the policy makers in regional development to understand better how to design programmes to address better the development needs of the regions, with their particular features.

Thus, the paper informs about the planned and the effective links of three elements in the process of policy making: (i) Regional development needs (particularly regional disparities) - (ii) Programmes designed and implemented, including volume of funding and the type of projects, - (iii) Observed change in the regions, regarding the regional disparities.

Regional development and reduction of the inter and intraregional disparities are addressed all over the world by national and transnational public policies. A particular case is the European Union (EU) Cohesion Policy, due to its geographical extension and a considerable amount of funds allocated through a large number of programmes. Thus, Cohesion Policy covers 98 regions (NUTS 1 level), comprising 276 NUTS 2 areas respectively, 1342 NUTS 3. NUTS is the official division of the EU for regional statistics (European Union, 2015). The Cohesion Policy is implemented through the European Structural and Investment Funds (ESIF) and is the main instrument for the implementation of the EU policies in the Member States (MS).

In general terms, the regional disparity indicates the degree to which the intensity of a certain phenomenon differs between regions. The concept of disparity may refer to regional differences in GDP per capita, productivity, unemployment rates or other dimensions of the regional activity.

The rich literature regarding the regional disparities reveals their multiple effects on the wellbeing of the people, but also the factors influencing them. The author looks particularly at the policies and the related instruments, including those regarding the conditions for economic development and employment, as key factors influencing the disparities.

Substantial funding is consistently allocated by the EU to the regions of the MS for regional development. Three hundred fifty-five (355) billion Euro (2011 prices) were allocated in the financial cycle 20072013 and 325 billion Euro in 2014-2020 [1]. At the national level, the 
funds allocated for the Cohesion Policy varies between less than $0.1 \%$ and $4 \%$ of GDP.

The needs and the funds allocated generate a high interest to the European Commission, the national governments and regions to design high impact programmes to produce the expected impact on the development of the regions and the reduction of disparities.

The link between the regional needs and the expected impacts of an intervention is discussed extensively in the literature. The theory of change provides models or explains in specific situations how actions undertaken can lead to the expected effects. Bondonio [2] highlights three categories of variables influencing the impact, the first one being "Variables regarding the funds available and allocated". Garcia and SanzMenendez [3] discuss the "competition for funding" as an indicator of competitiveness in the research field. Extending the concept to other fields, the author finds the competition of projects, a key variable part of the category mentioned above. This paper intends to build more knowledge on this variable and to link it to the practice in EU funds, aiming to inspire and guide policy makers in the design of the interventions.

The author captures in this paper a snapshot of the real links between the regional needs, the instruments created, and the outputs and results produced or achieved. The model proposed by the author is visualized in Figure 1.

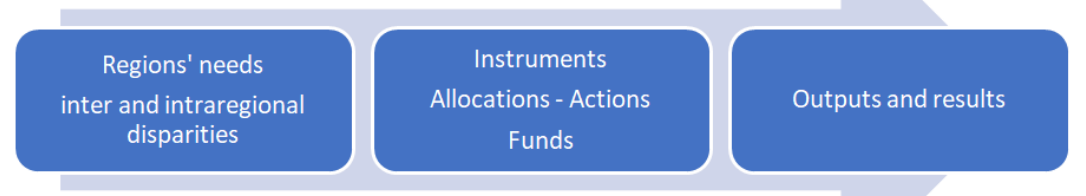

Figure 1. Needs - Instruments - Outputs \& results model (author concept)

The model may be used to answer key questions of the decision makers and programme managers, such as: (1) To what extent the funds addressed the appropriate target groups; (2) To what extent the programme generated the projects, the outputs and results as planned 
and expected; (3) Are the programme mechanisms adequate to address the regional disparities with their specific needs?

The model is tested in the current paper on the case of the first operational programme supporting the regional development policy in Romania, (ROP 2007-2013) and was limited to the interventions supporting business development at the regional level, more exactly microenterprises support.

The projects funded by ROP started implementation in 2009 and ended in 2015. Thus, there were used data at regional, local and project level over the entire period. For the enterprises receiving support, there were collected and used data also three years before the start of the project and one year after (2016) to capture the business performance before and after the support.

The paper is structured in four sections after the present introductory chapter, starting with the regional needs addressed, the situation before the programme implementation and the programme objectives and mechanisms as designed and planned.

The next section presents the outputs and the results of the programme and an analysis of their territorial distribution and relevant features to the regional needs. It also looks at the wider regions' economic and social context and changes compared to the start of the programme.

The final section draws the conclusions and further steps for analyzing the contribution of the programme to the objectives as they were formulated in the programme document.

\section{Designing and planning the interventions addressing regional disparities.}

For decades, the EU has been one of the most enthusiastic proponents of regional policy through its Cohesion Policy, one of the most substantial expenditure programmes in the EU budget [8].

In 2005- 2007 substantial effort was dedicated in Romania for the design of the Regional Operational Programme 2007-2013, aiming to identify the most effective solutions and design the mechanism to produce an impact on the regions [4].

Regional inter and intraregional disparities were considerable at the time of Romania accession in 2007 when Romania acceded in the 
European Union. In general, the territorial inequalities increased in the 90s during the transition to the market economy [5].

The regional disparities increased, becoming a feature of the Romanian economy, with a concentration of the economic growth around the capital, while other areas of the countries are effectively decoupled from the economic growth [4]. Significant disparities between the Romanian regions and other European regions were observed as well. Regarding purchasing power standard (PPS) in 2008, one year before ROP effectively started its implementation, as shown in Table 1 Romania was at $51 \%$ in the EU average and Region North East only $31 \%$.

Table 1. Purchasing power standard (PPS) per inhabitant in the percentage of the EU average in 2008 and 2016

\begin{tabular}{lll}
\hline PPS per inhabitant & $\% 2008$ & $\% 2016$ \\
\hline EU average & 100 & 100 \\
Romania & 51 & 58 \\
Bucuresti-Ilfov & 126 & 139 \\
Vest & 56 & 60 \\
Centru & 48 & 54 \\
Nord-Vest & 45 & 51 \\
Sud - Muntenia & 42 & 50 \\
Sud-Est & 40 & 46 \\
Sud-Vest Oltenia & 37 & 42 \\
Nord-Est & 31 & 36 \\
\hline
\end{tabular}

Source: author calculation based on Eurostat data

At the intra-regional level, the model proposed by Goschin, Constantin, Roman and Ileanu [5], classifies the counties (NUTS 2) on the absolute level and dynamics of a composite index of disparities, in four categories. The composite index included three variables: GDP per inhabitant, the unemployment rate and the average monthly net earnings.

Table 2. Categories of counties by the composite indicator

\begin{tabular}{ll}
\hline County category & Counties \\
\hline I GDP above average in & Timis, Cluj, Arad, Ilfov and \\
progress & Bucharest Municipality \\
II. GDP above average & Neamt, Botosani,
\end{tabular}


in decline

III GDP below average in progress

IV GDP below average in decline

\author{
Brăila, Tulcea, and others \\ Constanta, Satu-Mare, Arges, \\ and Mures \\ Teleorman, Hunedoara, \\ Giurgiu, Calarasi Ialomita Gorj \\ and others
}

Source: Goschin et al.,2008; adapted by the author.

Because the research focused on the microenterprises' support, the author analysed the situation before the implementation and the trend until 2016, one year after the support was provided. Most relevant indicators selected for analysis are (1) Number of microenterprises per 1000 inhabitants and (2) Number of employees in microenterprises. They were calculated using Eurostat data2: Population of active enterprises, Persons employed in the population of active enterprises.

Table 3. Descriptive statistics of the regional distribution of the Number of microenterprises per 1000 inhabitants and Number of employees in microenterprises.

\begin{tabular}{lll}
\hline Indicator & \multicolumn{2}{l}{$\begin{array}{l}\text { Number of microenterprises by } \\
1000 \text { inhabitants }\end{array}$} \\
\hline & 2008 & 2015 \\
\hline mean & 20.36 & 32.75 \\
min & 8.64 & 19,47 \\
max & 57.03 & 66.15 \\
Standard deviation & 8.63 & 9.26 \\
\hline Indicator & Employees in & microenterprises \\
& (number) & \\
\hline & 2008 & 2016 \\
\hline mean & 23765.4 & 20773.64 \\
min & 6258 & 6297 \\
max & 205080 & 162981 \\
Standard deviation & 30855.13 & 25505.54
\end{tabular}

Source: Eurostat and author calculation for the 42 counties of Romania

2 data source: Eurostat, Business demography by size class, class 0 and 1-9 employees); Average annual population to calculate regional GDP data (thousand persons) by NUTS 3 regions [nama_10r_3popgdp] 
Significant intraregional differences (NUTS 3) level regarding the active microenterprises, were found in 2008, one year before the implementation of the support measures to microenterprises, both as a number of microenterprises and employees in the microenterprises. (See table 3) Analysis of the variation of these indicators between 2008 and 2015 for each county reveal a strong dropdown in 2010, (see Figure 2 and Figure 3) and recovery after that. While overall in 2015 and 2016 the number of employees in microenterprises is still less than in 2008, in most of the counties, the number of microenterprises increased in all counties with an average of $66 \%$.

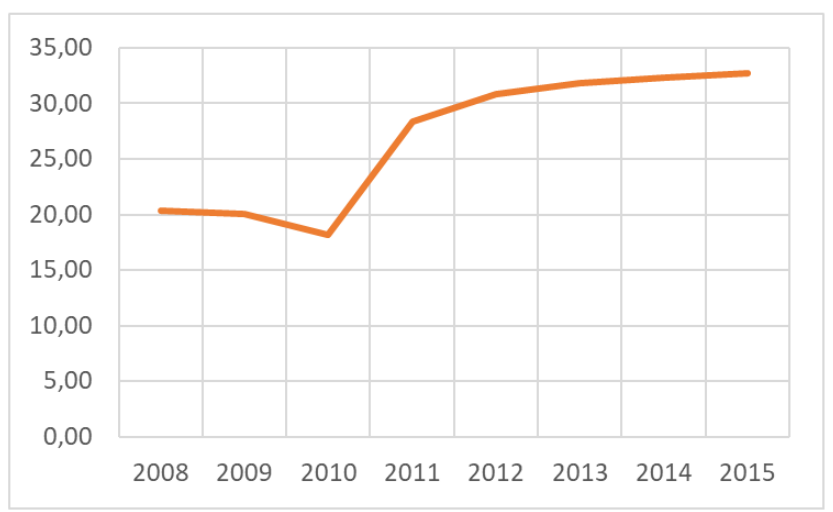

Figure 2. Number of microenterprises by 1000 inhabitants 2008-2015 Source Eurostat data and author processing

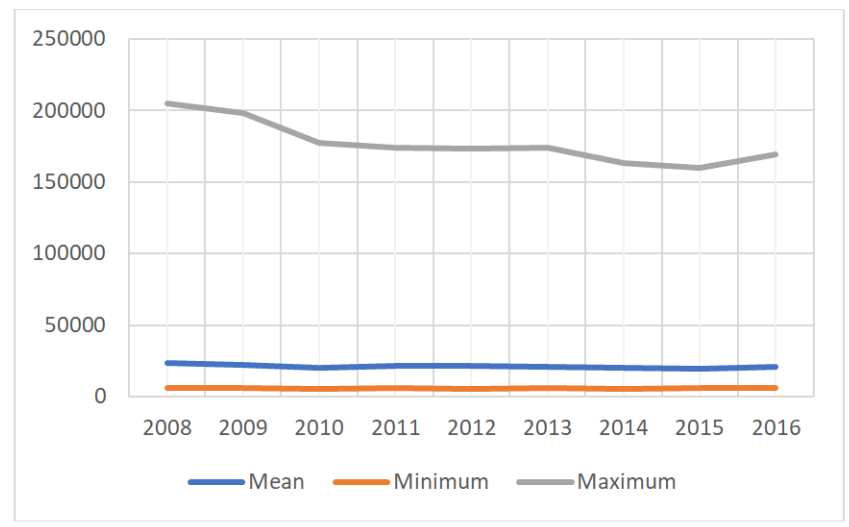

Figure 3. Number of employees in microenterprises 2008-2015 Source Eurostat data and author processing 
ROP 2007-2013 was designed to address the main regional development challenges in Romania. According to the official programming document ROP 2007-2013 [4] the programme aimed at contributing to the reduction of the interregional disparities as well as those inside the regions, between the urban and the rural areas, the urban centers, and the adjoining ones. One of the objectives of ROP was the "Increase of the regions' competitiveness as a business location." Balanced development of all the regions was envisaged through an integrated approach combining public investments in the local infrastructure with active policies to stimulate businesses and use of local resources.

To achieve this objective, the programme has planned measures to support the business environment, allocating 561.68 Mln Euro out of the 4.66 Bln Euro for the entire programme [4]. 3.96 Euro was the EU contribution to ROP 2007-2013. The programme expected 1500 projects (microenterprises) to be supported for investments, and 3000 new jobs to be created due to the investments supported.

The funds have been pre-allocated by regions considering several factors including sizes and development, but for each region, it was launched a competition for awarding the grant to the projects.

\section{The support received in the regions and the visible effects}

\subsection{The funds, the projects selected for funding}

Between 2009 and 2015, 2101 projects have been selected, granted with up to 200000 Euro funding from ROP 2007-2013 and implemented. 5402 applications have been submitted by microenterprises from all regions, but only 2001 were finalised. The projects had a total eligible value of 299.6 Mln. Eur.

One key issue in this research was the selection of variables considering what would best describe the change produced and what could be accessed.

The relevant variables were defined in the programme document and reflect the expected outputs and results at the programme level, as well as other features informing about the programme efficiency, as follows: the input variables (funding per project and number of projects), output variables number of jobs created/maintained, result indicators at 
project level (enterprise performance indicators: turnover, number of employees, debts, etc [6].

A database was built for all projects' beneficiaries selected for funding. The project data were extracted from the Ministry of European Funds public database (accessed at http://www.fonduriue.ro/transparenta/date-deschise, $19^{\text {th }}$ June 2017). The author added in the database additional data (publicly available) for each beneficiary, including the main business features, and performance indicators over 2009-2016 covering if possible at least one year before the implementation of the project and one year after.

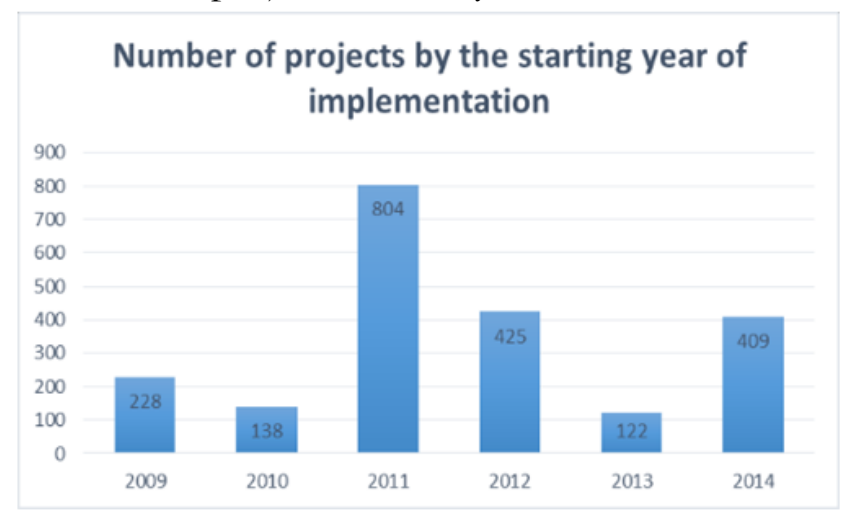

Figure 4. Distribution of projects and funding during the programme implementation

Source: Ministry of European Funds and author processing

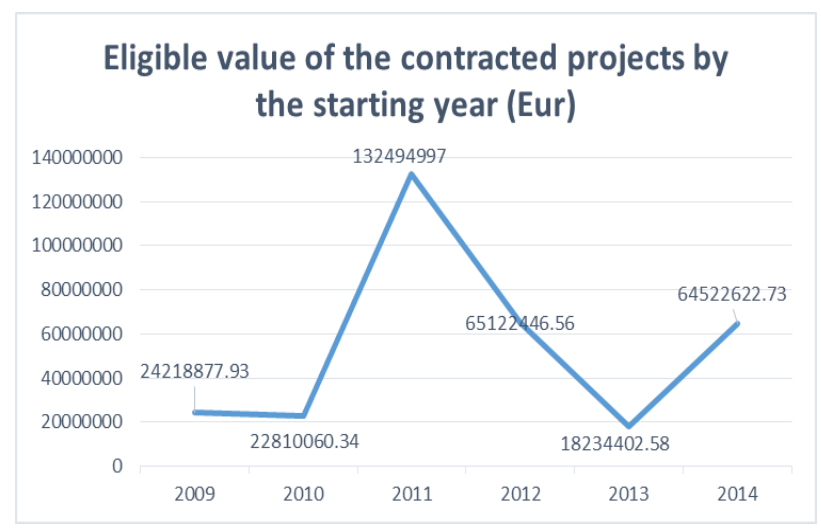

Figure 5. Distribution of funds contracted during the programme implementation

Source: Ministry of European Funds and author processing 
Two thousand one hundred twenty-eight (2128) projects were registered in the database and their distribution over the implementation period is reflected in Figure 4 and the corresponding funding the Figure 5.

The author focused the analysis on the period $2011-2016$ when most of the funding and projects were implemented. Moreover, 2011 was the first year after the hit of the economic crisis and the analysis could consider homogeneous external factors.

Therefore, the analysis was further carried on 1726 projects which were contracted after 2011.

The distribution of the projects by region reveal they are not correlated with the development needs or the stage of development. Thus, there are less developed regions attracting fewer projects than more developed regions (e.g., South-West and South-East compared to Bucharest-Ilfov or North West). Analysing as well the microenterprises sector in each region the conclusion is illustrated in Figure 6 the funding was not directed proportional to the need to support the number of microenterprises in the region.

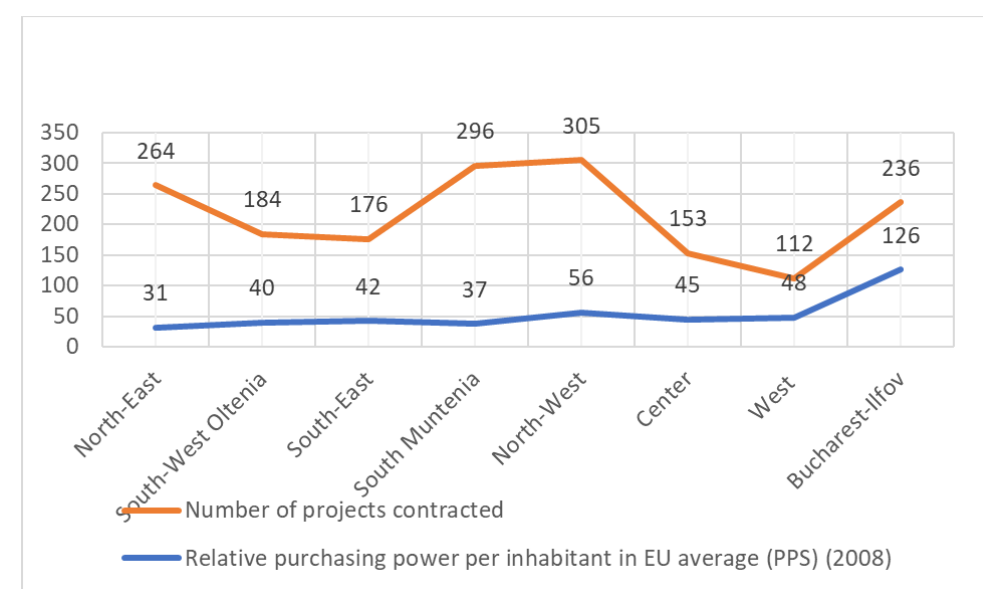

Figure 5 Comparison number of projects funded against the regional development level

Source: Ministry of European Funds and author processing 


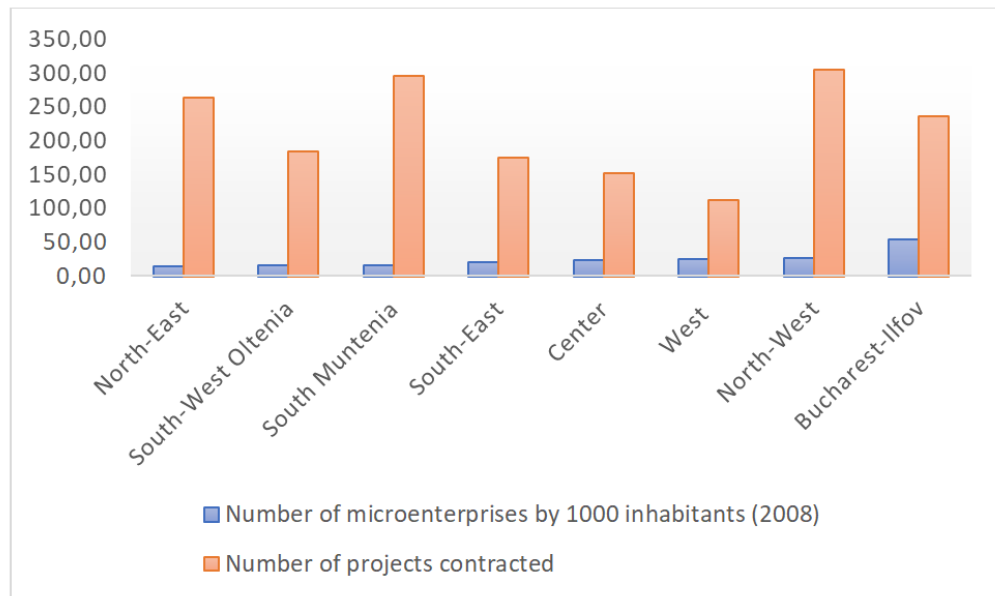

Figure 6 Comparison number of projects funded against the number of microenterprises by region

Source: Ministry of European Funds and author processing

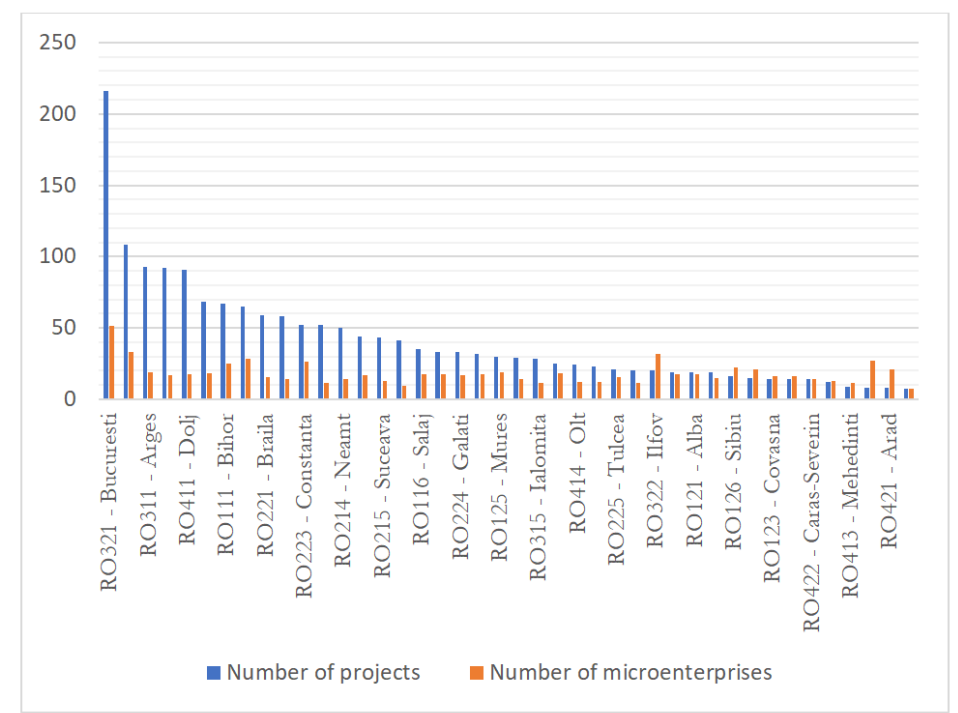

Fig 7. Number of projects by county compared to the number of existing microenterprises (2010)

Source: Ministry of European Funds and author processing

The Pearson correlation coefficient applied for the two data sets (projects funded by county and Number of microenterprises existing in the county before the projects selection and implementation) indicates a 
positive and relative strong correlation $(0,6479)$. This proves that the funding is not accessed by the counties with a less developed SME (microenterprise) sector, but by counties with a better capacity of accessing funds, i.e. more existing and stronger SMEs. The selection of microenterprises based on competition is the main factor leading to this concentration of funds in the counties with a higher capacity of development, and not necessarily to those having a higher need.

The distribution of funding by sector depended to a large extent to the development opportunities in the eligible sectors. The programme offered the funding to a large number of sectors in production and services. The project statistics (visualized in Figure 8) shows that two sectors attracted $24 \%$ of the total number of projects funded, namely "Activities regarding human health" and "Building constructions." Other sectors well represented in the list of projects funded are other construction services, car repairing, hotels, engineering, management, and business services, publicity and market search, IT services.

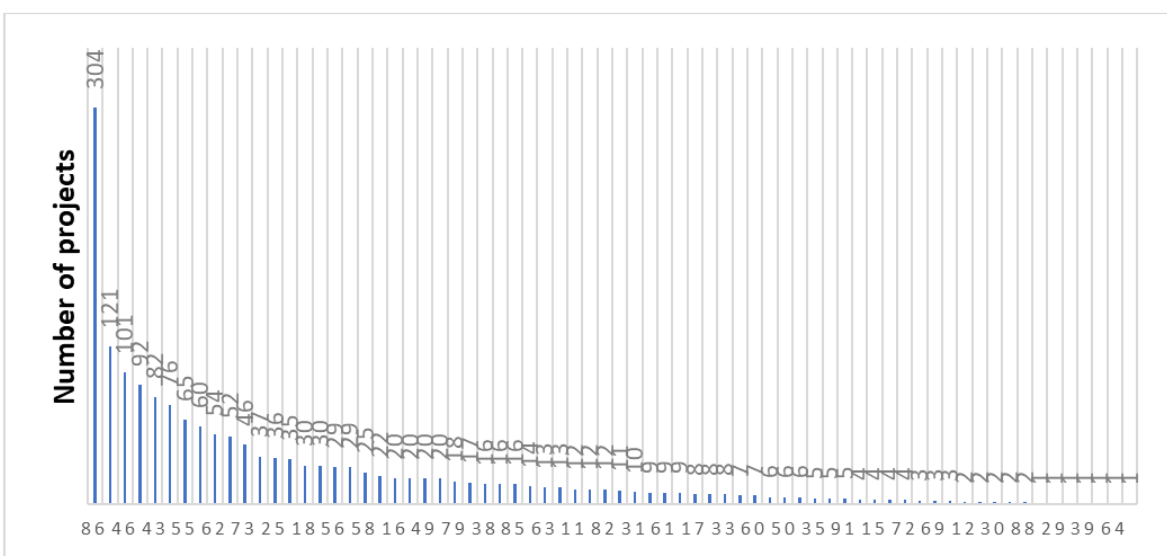

Activity type NACE codes

Figure 8. Distribution of projects by activity type

Source: Ministry of European Funds and author processing

For the programme, the main output is the number of projects. From the development point of view, it is the number of supported microenterprises that continued their activity.

According to the programme final report, an average of 3 new jobs per project was created.

The author analysed the variation of the number of employees in the microenterprises funded. This variation may be due to other factors 
than the jobs reported as created directly by the project. However the investment is expected to strengthen the microenterprise and possibly lead to an extension of the company including regarding sizes.

Out of the 1726 observations, two were excluded as being outliers with more than +200 employees variation and a loss of 116 . Three hundred seventy-three (373) microenterprises had in 2016 less or the same number of employees than in 2010 before the project implementation. The higher loss in a number of employees is 18 , and the average is 2.13 .

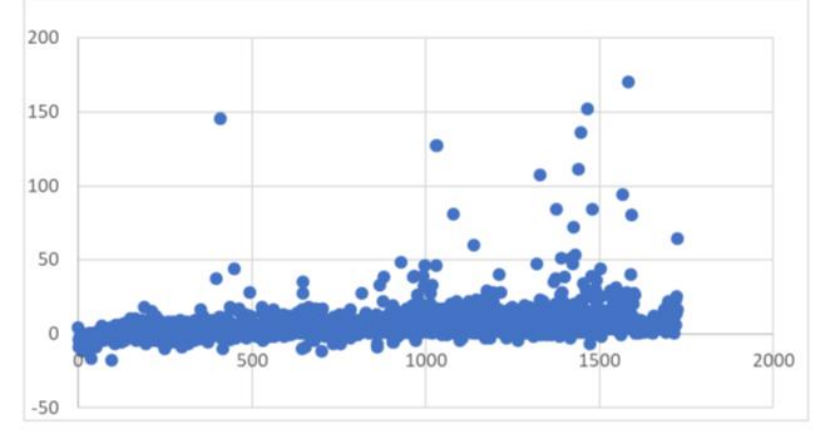

Figure 9. Variation in the number of employees between 2010 and 2016 for 1724 firms

Source: Ministry of European Funds, Ministry of Finance and author processing

One thousand three hundred fifty-one (1351) microenterprises funded had in 2016 more employees than in 2010, before the start of the implementation of the projects. The average gain in the number of employees is 8.66.

The analysis of the turnover of the microenterprises supported showed that 14 of them stopped their activity by 2016 and 404 microenterprises registered a small turnover than in 2010 before the project implementation. The largest part of the microenterprises funded are still active in 2016, and the increase of the turnover is for some of them very large, but the average is around $23 \%$.

\subsection{Analysis of the relevance of the intervention to the need to reduce the disparities}

The author looks first on the observable change in disparities in 2016 against 2008. 
Three indicators were analysed as being most relevant for the programme support: the number of microenterprises, the number of employees in the enterprises and the more general indicator, the GDP at the region level.

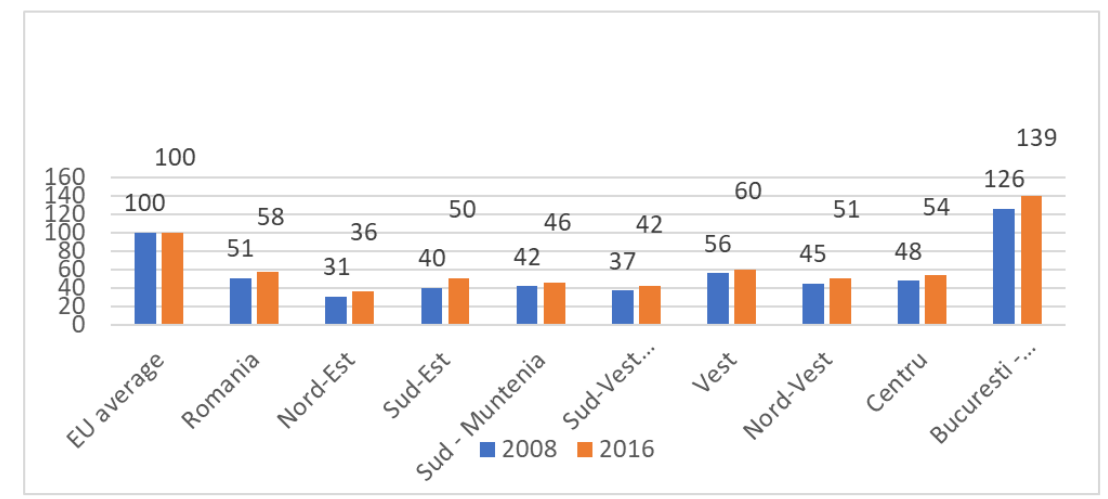

Fig 10 GDP p.c. in 2016 and 2008 (index, EU=100)

Source: Author calculations based on Eurostat data.

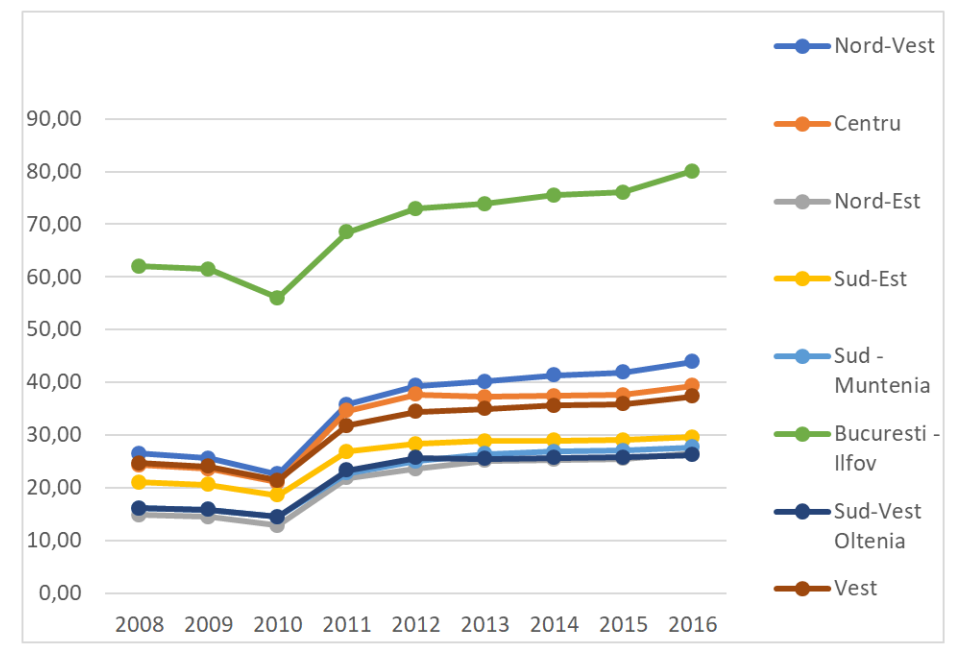

Fig 11. Number of microenterprises per 1000 inhabitants, 2008-2016 Source: Author calculations based on Eurostat data. 


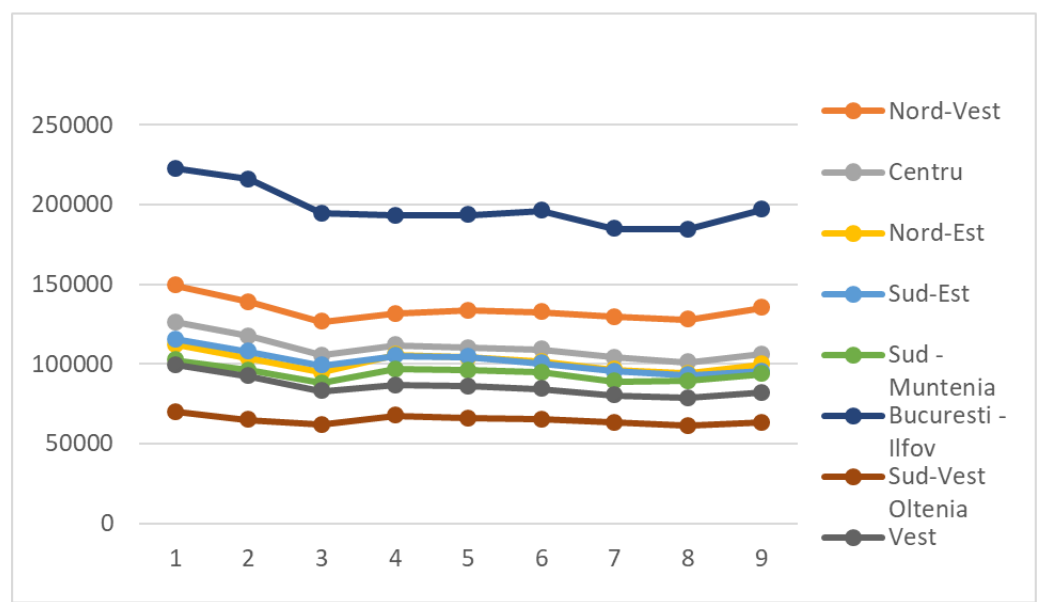

Fig 12. Employees in microenterprises, 2008-2016.

Source: Author calculations based on Eurostat data.

The statistical evidence confirms that there are important economic disparities between Romanian regions regarding the number of enterprises and the number of employees in registered enterprises.

These disparities are correlated with the regional development gap, as expressed by the distribution on GDP/capita by regions: the more developed regions (Bucharest Ilfov, South Muntenia, or Center) are the ones with the highest number of enterprises and the largest number of employees.

At the same time, these regions attract the larger share of funds, as expressed by the number of projects.

The model Needs - Intervention - Outputs and Results tested offer the following key findings:

- the needs are unevenly distributed across Romanian regions

- The number of projects proves an uneven distribution of the attracted funds across Romanian regions.

- The projects and the attracted funds in the ROP programme are not correlated with the development needs existing in specific regions.

- The programme and results outputs are coherent with the needs, but there is no evidence of coherence with the inter and intraregional disparities. 
These findings are in line with Roman and Gotiu [11] that quantified important differences by counties in the efficiency of structural funding for improving educational infrastructure.

\section{Conclusions}

The funding is not directed to those regions or counties with higher development needs but to those with a higher absorption or development capacity. Not even in the case of regions where a preallocation of funds is decided by the programme management did not prove a focus on less developed regions.

There is an evident positive impact of the programme, but not stimulated towards specific interregional or intraregional disparities.

Th European Commission launched the discussion on regional disparities with the following question:

"What is needed to achieve stronger economic growth and increased well-being, therefore, differs from region to region." the 'right' policy mix and a 'real' feeling of ownership may well matter more than the amount of funding provided and where it is spent [7].

The research presented above may offer some conclusions and directions for further research, as follows.

The author conclusion is that the mechanism of implementation should be the main factor in directing the support towards the regions/ counties with the higher needs in terms of reduction of the disparities. This can be ensured early from the design phase of the programme. In parallel, the capacity for accessing the funds and development should be supported in the less developed areas.

It appears clearly that an integrated approach of regional needs identification, the design of customized instruments on specific needs at the territorial level and effective implementation is the answer to how to reduce the regional disparities. Programme managers have to work together with researchers in a large number of fields, creating multidisciplinary teams in various phases of the programme design and implementation.

Further research will be focused on other factors influencing the impact of funding on business performance.

\section{References}

[1] Bachtler J, Mendez C. Regional Policy in a Changing Europe, Annual Review of the Regional Policy in Europe [Internet]. Eprc-strath.eu. 2018 
[cited 12 January 2019]. Available from: http://www.eprcstrath.eu/public/dam/jcr:1067b233-6c66-4e6e-abf8601373becd00/EoRPA\%20Paper\%2017 1.pdf.

[2] Bondonio D. Impact identification strategies for evaluating business incentive programs. POLIS Working Papers 129, Institute of Public Policy and Public Choice - POLIS; 2009. Retrieved from http://polis.unipmn.it/pubbl/RePEc/uca/ucapdv/bondonio145.pdf

[3] Garcia C, Sanz-Menéndez L. Competition for funding as an indicator of research competitiveness. Scientometrics. 2005;64(3):271-300.

[4] Guvernul Romaniei. Programul Operational Regional 2007-2013. 2007

[5] Goschin Z, Constantin D, Ileanu B, Roman M. The current state and dynamics of regional disparities in Romania. Romanian Journal of Regional Science. 2006;2(2).

[6] Lucaciu L. A Look at the Evaluation Framework for Smart Growth Programmes. Revista Romaneasca pentru Educatie Multidimensională. 2018;10(3):60-67.

[7] European Commission. Expert seminar on the use of Cohesion policy funding to support growth and job creation in the EU [Internet]. 2015. Available from:

https://ec.europa.eu/regional_policy/sources/docgener/evaluation/pdf/ expost2013/wp1_expert_seminar_summary.pdf

[8] Bachtler J, Begg I. Beyond Brexit: Reshaping policies for regional development in Europe. Papers in Regional Science. 2018;97(1):151-170

[9] Guvernul Romaniei. Raportul final de implementare POR 2007-2013 [Internet]. 2017. Available from: http://www.fonduri-ue.ro/por2007\#rezultate

[10] European Union. Regions of the European Union, Nomenclature of the territorial unit for statistics NUTS 213/EU-28. Publications Office of the European Union; 2015.

[11] Roman M, Gotiu (Lucaciu) L. Non-parametric methods applied in the efficiency analysis of European structural funding in Romania. Journal of Applied Quantitative Method. 2017;12(2).

[12] Bachtrögler J, Hammer. Who are the beneficiaries of the structural funds and the cohesion fund and how does the cohesion policy impact firm-level performance? [Internet]. Ideas.repec.org. 2018. Available from: https://ideas.repec.org/p/oec/ecoaaa/1499-en.html 